\title{
Variation of Calcium Oxalate (CaOx) Crystals in Porang Corms (Amorphophallus muelleri Blume) at Different Harvest Time
}

\author{
Nurul Chairiyah, Nunung Harijati, Retno Mastuti \\ Department of Biology, Faculty of Mathematics and Natural Sciences, University of Brawijaya, \\ Malang, Indonesia \\ Email: nchairiyah@gmail.com,nHarijati@gmail.com
}

Received 12 January 2016; accepted 19 February 2016; published 22 February 2016

Copyright @ 2016 by authors and Scientific Research Publishing Inc.

This work is licensed under the Creative Commons Attribution International License (CC BY). http://creativecommons.org/licenses/by/4.0/

c) (i) Open Access

\begin{abstract}
Harvest time is assumed to potentially influence shape and size variation of calcium oxalate (CaOx) crystals; therefore it needs to be observed microscopically. This research used porang corms from the second growing period which were planted to produce the vegetative phase of third growing period. These corms were obtained based on the harvest time had determined. The harvest time was determined, i.e. 1$)$ at two weeks before the plants shed $\left.\left(R_{0}-1\right) ; 2\right)$ when the plants shed $\left(R_{0}\right)$ and 3) at two weeks after the plants shed $\left(R_{0}+1\right)$. Slides for microscopic observation were obtained from slices on the edge and center of porang corms. Organ slices were cleared using modified clearing method. Parameters observed were the shape and the size of CaOx crystal. The variations of styloid, prism, druse and raphide crystals found in porang corms at the three harvest time were 1, 2, 3 and 37 variations respectively. The variation of $\mathrm{CaOx}$ crystals tended to be same in porang corms at three harvest times. The variation of these crystals tended to be static. It is also known that raphide crystal has the greatest variation amount. On the contrary, styloid crystal has the fewest variation amounts. This abundance of a number of raphide crystal variations is possibly due to its role as a defense mechanism in porang corms.
\end{abstract}

\section{Keywords}

Harvest Time, Variation, Shape, Ca0x Crystal, Porang Corms

\section{Introduction}

$\mathrm{CaOx}$ crystal is an ergastic material in plants formed by the binding of calcium (Ca) and oxalic acid compound

How to cite this paper: Chairiyah, N., Harijati, N. and Mastuti, R. (2016) Variation of Calcium Oxalate (CaOx) Crystals in Porang Corms (Amorphophallus muelleri Blume) at Different Harvest Time. American Journal of Plant Sciences, 7, 306-315. http://dx.doi.org/10.4236/ajps.2016.72030 
$\left(\mathrm{C}_{2} \mathrm{H}_{2} \mathrm{O}_{4}\right)$ [1]-[10]. CaOx crystal in plants was firstly described by Leeuwenhoek in the late $1600 \mathrm{~s}$ using simple light microscope. It was observed in the most of plant tissues and organs as an intracellular or extracellular deposit. Intracellular $\mathrm{CaOx}$ crystal was formed in a cell vacuola which is special for crystal formation called idioblast crystal. CaOx crystal formation in plants needs 3\% - 80\% oxalate and 90\% Calcium (Ca). Crystal morphology, amount, distribution and cell shape that influence crystal formation are factors play role in determination of $\mathrm{CaOx}$ crystal function [3]. These crystals might reflect sunlight to prevent chloroplast degradation in palisade cells [11]. On the other hand, $\mathrm{CaOx}$ crystals have a role in defense mechanism in plants to protect them from herbivorous animals and insects inasmuch as they might cause inflammation and irritation on mouth and throat if it was consumed [3] [10]. Oxalic acid which is constituent of CaOx crystal also played role in defense mechanism towards planthopper and aphid. These acid which is a grouped of strong acid is toxic against insect and herbivorous animal. Consumption of plant contained oxalic acid with high levels can lead to death in human. It is happened because oxalic acid can cause the damage of kidney [12].

CaOx crystals which are often found in plants generally are raphide, druse, prism, styloid and sands [3] [13]. Druse crystal can consist of one or more per cell [3]. It is usually found in an irregular specific cell (star shape, spherical shape and etc) [14]. Raphide crystal was a rectangular styloid crystal which had been thickened and lengthened [3]. It is usually found in parenchyma cells. These chrystals can lead to allergic reaction against animal and human [14]. Prism crystal generally have a regular shape [14]. It shaped like a rhomohedral box. Sand crystal is a crystal was derived from an association of a small angular crystal [3]. Styloid or pseudoraphide crystal had a shape thicker than commom raphide crystal and is usually solitary in the cells [7].

Porang (Amorphophallus muelleri Blume) is a bulbous plant which is grouped in Araceae Family. It is native to tropical areas. Porang corms are good food source for diabetics because it contained low glycemic index. Foodstuff contained low glycemic index can suppress the increase of blood sugar levels for diabetics. However, porang also will cause irritation if it is consumed. This irritation is actually caused by CaOx crystals [15]. Prychid et al. [16] stated that plant which is grouped into the genus of Amorphophallus accumulated CaOx crystal, generally in raphide and druse crystal. However, it was possible to find other crystal shapes in Amorphophallus because some plant species which were grouped in Family Araceae could accumulate other crystal shape in their tissue [13] [17]-[22]. Based on the previous research, porang accumulated four crystal forms: 1) raphide; 2) druse; 3) prism; and 4) styloid. Each form has some variation, i.e. Raphide crystal has 49 variations, druse crystal has 10 variations, prism crystal has eight variations and styloid crystal has five variations [23].

In East Java, Porang corms were generally harvested in the third growth period when the plants shed and after plants shed because it is suspected in corms reaching the highest content at that time compared with the content of glucomannan in corms harvested before plants shed. However, consumer demand for porang corms is high enough recently. It cause porang corms are harvested earlier, i.e. before the plant shed (personal communication, 2013). Different harvest time influence on the accumulation of chemical compounds in the tubers caused by differences in metabolism [24], especially the accumulation glucomannan, and calcium oxalate (CaOx).

The variation of $\mathrm{CaOx}$ crystals in porang corms is assumed to vary during corm development. It was based on the statement of Chua [25] and Hamadina [26]. They explained that during leaves development process, there are transition processes in araceae corms, one of them is Amorphophallus corm. These transition processes are source and sink transition. These process is related on the changing of corm function, from energy reserve source for bud development (source), become an accumulation place for excessive photosynthesis result (sink) [25]. It was assumed that these transition process was followed by oxalate content transition. Çaliskan [27] and Moore et al. [28] stated that oxalate content variation was based on plant age, plant variety, development condition, development stage, soil type, season, and climate. Çaliskan [27] also explained that in some plants, one of them is rhubarb (Rheum rhabarbarum), oxalate content tended to be higher when it was mature. However, oxalate content in other plants, e.g. spinach, sugar beet leaves and banana, tended to be lower when they were mature. Another research also described that $\mathrm{CaOx}$ content at the three development stages in some grass plants, have some variation in each development stage. In the last stage of plant development, oxalate content in some grass plants tended to be higher than it in the early stage [29]. Oxalate content transition was assumed can affect variation of $\mathrm{CaOx}$ crystal in porang. The influence of porang harvest time in one growth period towards the variation of $\mathrm{CaOx}$ crystal is still not reported, therefore it is interesting to observe variation of crystal on corms harvested from before until after plants shed. 


\section{Material and Methods}

\subsection{Preparation of Plant Material}

Porang corms were derived from Sumberbendo, Saradan Sub-district, Madiun, East Java. This research used porang corms from the second growing period which were planted to produce the vegetative phase of third growing period. On 200th day after planting, the harvest time was determined, i.e. 1) at two weeks before the plants shed $\left(R_{0}-1\right)$; 2 ) when the plants shed $\left(R_{0}\right)$ and (3) at two weeks after the plants shed $\left(R_{0}+1\right)$.

\subsection{Preparation of Microscopic Slide}

Samples for microscopic slides were derived from the tissue slices of the edge and centre part of the corms. The making of semi-permanent slides used modified clearing method of Ilarslan et al. [30]. Each part (the edge and the centre part) of the corms had three slides to be observed. The organs were sliced using sliding microtome with thickness $\pm 10 \mu \mathrm{m}$. The tissue slices were soaked in $\mathrm{NaOH} 5 \%$ and were incubated in oven at $37^{\circ} \mathrm{C}$, for \pm 24 hours. Furthermore, the tissue slices were soaked in commercial sodium hypochlorite solution $50 \%$ for one hour to clear the tissue and then they were rinsed under running water (or with plenty of water). Furthermore, they were soaked with various concentration of ethanol, starting from 30\%, 50\%, 70\%, 80\%, for 10 minutes each and they were soaked with $\mathrm{EtOH} 100 \%$, for 5 minutes. After that, the tissue slices were placed on the object glasses that had been spilled with hoyer and they were covered with the cover glasses.

\subsection{Microscopic Observation}

Microscopic slides were observed with binocular light microscope (Olymphus CX31 type). Variety of CaOx crystal was observed at $100 \times-1000 \times$ magnification while density of $\mathrm{CaOx}$ crystal was counted at $100 \times$ and $1000 \times$ magnification. CaOx crystals observed at 1000× magnification were grouped in small crystals, whereas $\mathrm{CaOx}$ crystals observed at $100 \times$ magnification were grouped in big crystals. Furthermore, CaOx crystals that were found in microscopic slides were documented using digital camera.

\section{Result and Discussion}

\section{Shape Variation of Calcium Oxalate Crystals (CaOx) in Porang Corms (A. muelleri $\mathrm{Bl}_{\text {. }}$ ) at the Different Harvest Times}

In general we found four basic shapes of $\mathrm{CaOx}$ crystals in porang corms at three harvest times, i.e. 1) druse; 2) raphide that consists of long and short crystals; 3) prism and 4) styloid. These crystals highly varied depending on their size and type. These results were similar to the result of Chairiyah et al. [23] which stated that porang (A. muelleri Bl.) accumulated four $\mathrm{CaOx}$ crystals, i.e. 1) druse; 2) raphide; 3) prism and 4) styloid. On the contrary, Suweg (Amorphophallus campanulatus), which is member of Araceae family, accumulated only two types of CaOx crystals, i.e. druse and raphide crystals [31].

Crystal variations found in this research were in regard to size, crystal structure, constituent unit, color, and type. However, crystal variations found in this research was fewer than it was in the previous research. In the previous research, Chairiyah et al. [23] found 72 crystal variations in porang, whereas in this research, it was found only 43 crystal variations. Slight variations of $\mathrm{CaOx}$ crystals found in this research might be due to lack of nutrition in planting media, therefore formation of various types of crystal was limited. On the other hand, type variations of $\mathrm{CaOx}$ crystals tended to be the same at three harvest times, therefore it could be said that different harvest times had no effect on $\mathrm{CaOx}$ crystals variations (Table 1). Based on the result of this research, it is known that styloid crystal only has one variation. On the contrary, variation of raphide crystal has the greatest amount which is found in porang corms, i.e. 37 of variations. It was assumed to relate in its function as defense mechanism against insects and herbivorous animal. Sakai et al. [32] stated that raphide crystals were often formed in specific cells produced toxin. These crystals facilitated the toxin through the skin of herbivorous animal. The ingestion process of plant tissue contained raphide crystals usually caused irritation on mouth and throat of herbivorous animal. This irritation is happened mechanically by the raphide crystal or chemically by toxin which is contained in crystal [32].

\section{a. Druse Crystals}

Druse crystal found in porang corms had only three variations, i.e. solid, semisolid and loosely druse. This 
Table 1. The variation of $\mathrm{CaOx}$ crystals in porang corms (A. muelleri) at three different harvest times.

\begin{tabular}{ccccc}
\hline \multirow{2}{*}{ No } & Crystal shapes & \multicolumn{3}{c}{ Porang corms (\%) } \\
\cline { 3 - 5 } & Raphide $\left(\mathrm{n}^{\mathrm{a}}=37\right)$ & Before plants are shed & When plants are shed & After plants are shed \\
\hline 1 & Druse $\left(\mathrm{n}^{\mathrm{a}}=3\right)$ & 100 & 100 & 100 \\
2 & Prism $\left(\mathrm{n}^{\mathrm{a}}=2\right)$ & 100 & 100 & 100 \\
3 & Styloid $\left(\mathrm{n}^{\mathrm{a}}=1\right)$ & 100 & 100 & 100 \\
4 & 100 & 100 & 100 \\
\hline
\end{tabular}

${ }^{\mathrm{a}}$ Whole number variation morphology of CaOx crystal, which $\mathrm{n}=100 \%$.

classification of druse crystal was based on the difference of arrangement of globular crystal and the constituent unit (Table 2). The diameter range of druse crystals found in porang corms had only between 20 - $80 \mu \mathrm{m}$ in length. Small druse crystals were not found in this observation. Similar to diameter range of druse crystals observed by Harijati et al. [33] in porang, it had only between 24.8 - $37.2 \mu \mathrm{m}$ in length. Based on the diameter size, druse crystals are gouped into two categories, i.e. small and large druses. Small druse is a druse crystal which had $24.8 \mu \mathrm{m} \pm 2.96 \times 10^{9}$ in diameter, whereas large druse is a druse crystal which had $37.2 \mu \mathrm{m} \pm 3.76 \times 10^{9}$ [33]. On the other hand, there were not found druse crystals that looks like noodle lump, in case it was observed in weak magnification as stated by Chairiyah et al. [23].

The globular arrangement of semisolid druses generally looks concave on the centre part; therefore these crystals looks like rings, in case they were observed in weak magnification (Figure 1(b)). On the contrary, globular arrangement of solid druses formed perfect globular. There was no concavity on the centre part; therefore these crystals looked like roses, in case they were observed in weak magnification (Figure 1(a)). The globular arrangement of loose druses formed imperfect globular, therefore these crystals looked like loose glass flakes, in case they were observed in weak magnification (Figure 1(c)). In this observation, Druse crystals generally found in specialized cells were named idioblast cells. However, there was also druse crystals found in damaged idioblast cell (Figure $\mathbf{1}(\mathbf{d})$ ). It was assumed because of the cycle of idioblast formation.

These results were significantly different with Chairiyah et al. [23] which stated that small druses found in corms relatively abundant and the diameter of druse crystal could reach $135 \mu \mathrm{m}$. The difference of druse variations might be due to genetics and environmental factors, e.g. planting media. These founding are supported by Franceschi \& Nakata [3] who stated that, crystal size variations in one species were influenced by intrinsic factors, e.g. cell function into crystal formation and environmental factors, e.g. calcium (Ca) content which was available during crystals formation. Prychid et al. [16] also stated that druse crystals found in all Amorphophallus sp. had variations in diameter and the number of crystal, ranging from one to several small crystals in one idioblast. Each of them was consisted of various crystals that were attached together.

\section{b. Raphide Crystal}

Raphide crystals were found in the form of single and bundle crystals (Figure 2(b)) that had black, brown, dark brown, reddish brown and transparent color. They had various sizes ranging from 130 - $260 \mu \mathrm{m}$ for long raphide, 30 - $80 \mu \mathrm{m}$ for short one and 15 - $20 \mu \mathrm{m}$ for the small raphide. In this observation, classification of raphide crystals is based on the difference of size, of shape and of color and on the arrangement of crystal was found in corms tissue (Table 3). Harijati et al. [33] also classified raphide crystal in porang, based on the crystal length, into three categories, i.e. (1) $<200 \mu \mathrm{m}$, (2) 200 - $300 \mu \mathrm{m}$, and (3) >300 $\mu \mathrm{m}$. However, raphide crystals were found in this research commonly had smaller size than it was found by Harijati et al. [33]. The difference of raphide crystal size can be influenced by the dosage and mineral content of fertilizer, particularly calcium (Ca) [33].

Organized bundle raphide crystals consisted of a group of single raphide crystals that attached to each other (Figure 2(a), Figures 2(c)-(h)). On the other hand, unorganized bundle raphide crystals consisted of single raphide crystals not attached together and was arranged irregularly in spite of still being with in a group. Bundle straight edge of raphide crystals consisted of single raphide crystals arranged in parallel and attached to each other (Figure 2(a)). On the contrary, bundle raphide crystals with not straight edge consisted of single raphide crystals arranged in unparalleled form (Figure 2(i)). In group of Bundle raphide crystals, there was one type of crystal that had typical structure, i.e. punctured structure (Figures 2(f)-(h)). Bundle punctured raphide crystal consisted of two or more raphide crystals that were laid very close, and made these groups intersected. 


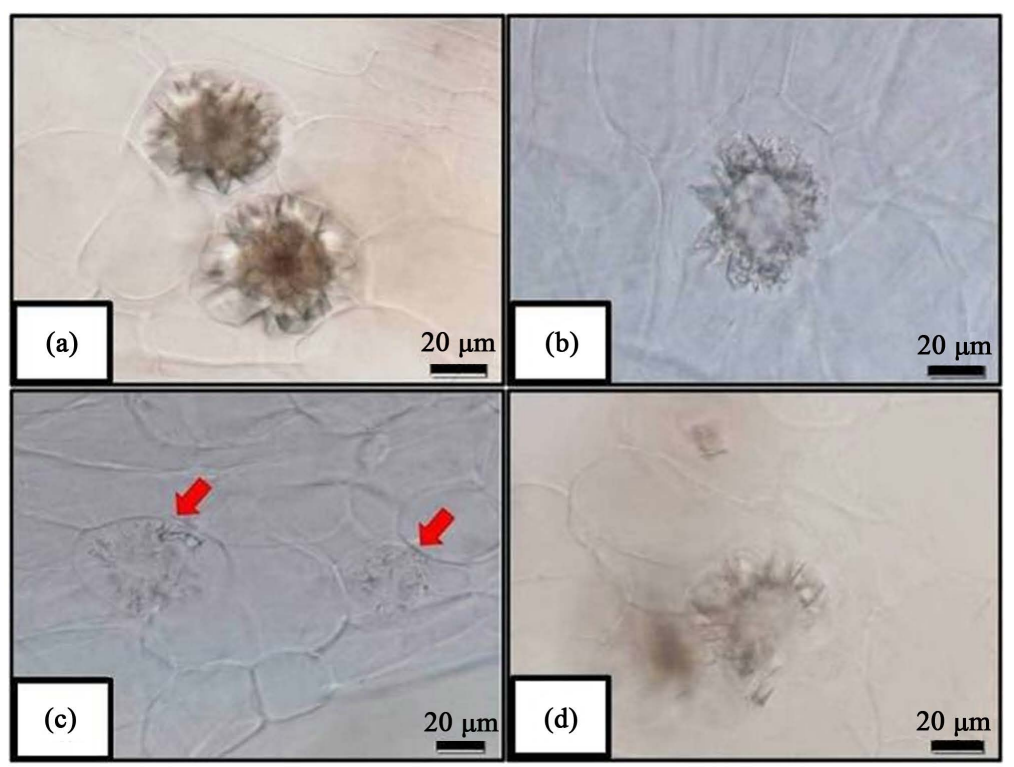

Figure 1. Variations of druse crystals that were found in porang corms: (a) solid druse crystal; (b) semisolid druse crystal; (c) loosely druse crystal (it is showed by red arrows); (d) damaged crystal idioblast.

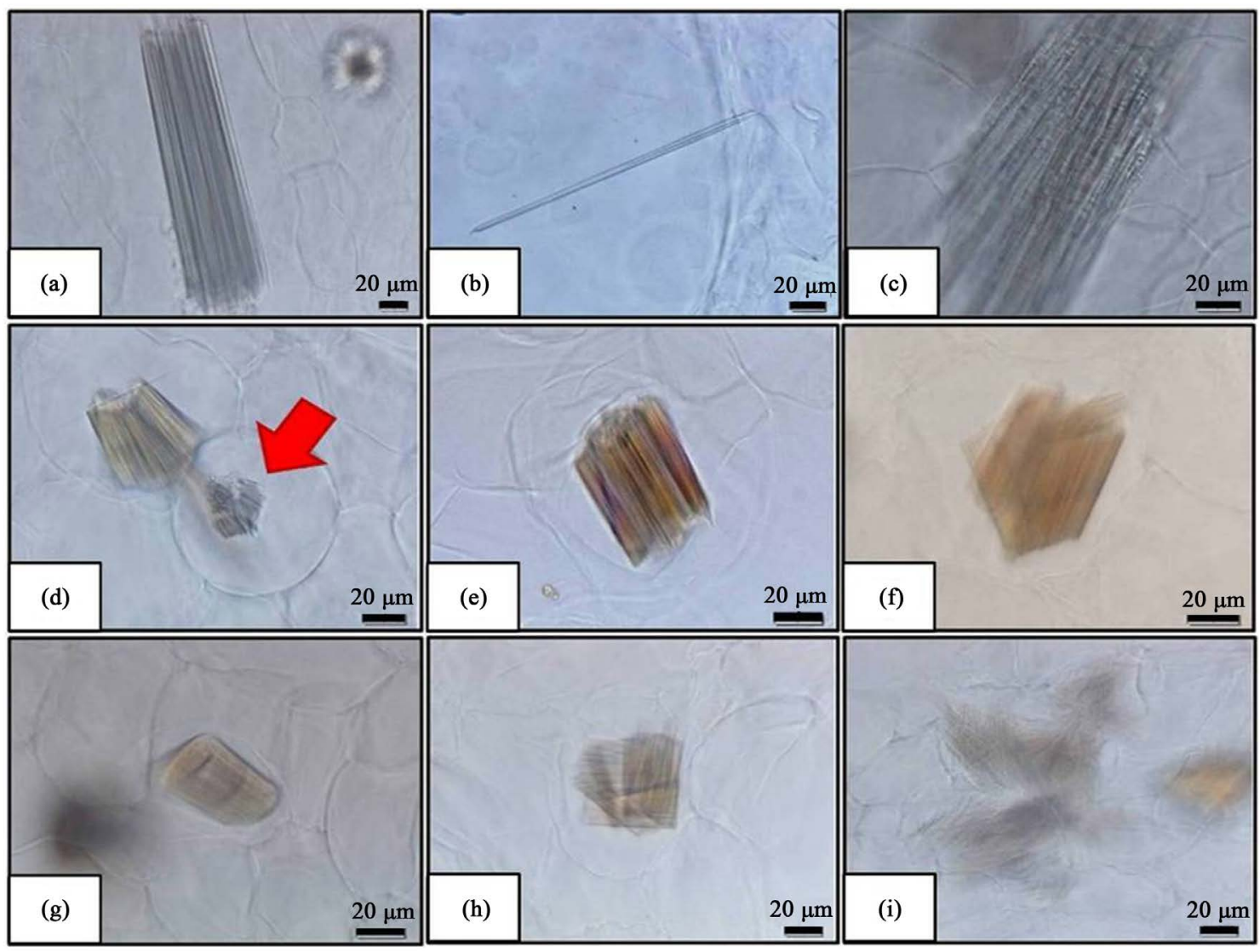

Figure 2. Variations of raphide crystals that were found in porang corms: (a) black long bundle straight edge raphide crystal; (b) long single raphide crystal; (c) fragile raphide crystal; (d) small raphide crystal (it is showed by red arrows); (e) reddish brown short bundle not straight; (f) brown short raphide crystal that punctured each other making prism shape; (g) dark brown short raphide crystal that punctured each other making silinder shape; (h) dark brown short raphide crystal that punctured each other with not neat organized; (i) black short hair flakes raphide crystal. 
Table 2. The variations of druse crystal in porang corms (A. muelleri Bl.)

\begin{tabular}{cccc}
\hline Types & Diameter $(\mu \mathrm{m})$ & Gobular forms & Constituent unit \\
\hline Solid druse & $20-80$ & Densely & Like rose petals \\
Semisolid druse & $20-80$ & Only on the edges & Like rose petals \\
Loose druse & $20-80$ & There was a distance/tenuous & Like glass flakes \\
\hline
\end{tabular}

Table 3. Variations of raphide crystal in porang corms (A. muelleri Bl.).

\begin{tabular}{|c|c|c|c|c|c|c|c|}
\hline \multirow[t]{2}{*}{ Type } & \multirow[t]{2}{*}{ Color } & \multirow[t]{2}{*}{ Long $(\mu \mathrm{m})$} & \multirow[t]{2}{*}{ Thickness $(\mu \mathrm{m})$} & \multirow{2}{*}{$\begin{array}{c}\begin{array}{c}\text { Neatness of } \\
\text { crystal edges }\end{array} \\
\text { Straight }\end{array}$} & \multicolumn{2}{|c|}{$\begin{array}{c}\text { Whole crystalline } \\
\text { organization }\end{array}$} & \multirow{2}{*}{$\begin{array}{c}\text { Additional information } \\
\left.-_{-*}^{*}\right)\end{array}$} \\
\hline & & & & & $\mathrm{O}^{\mathrm{a}}$ & $\mathrm{N}^{\mathrm{c}}$ & \\
\hline & & & & Not straight & $\mathrm{O}^{\mathrm{a}}$ & $\mathrm{N}^{\mathrm{c}}$ & $-_{-}^{*}$ \\
\hline & & $130-260$ & $\pm 4-6$ & Not straight & $\mathrm{O}^{\mathrm{a}}$ & $\mathrm{nN}^{\mathrm{d}}$ & $\left.-^{*}\right)$ \\
\hline & & & & Not straight & $\mathrm{O}^{\mathrm{a}}$ & $\mathrm{nN}^{\mathrm{d}}$ & Puncture \\
\hline & & & & Not straight & $\mathrm{U}^{\mathrm{b}}$ & $\mathrm{nN}^{\mathrm{d}}$ & $\left.-^{*}\right)$ \\
\hline & & & & Straight & $\mathrm{O}^{\mathrm{a}}$ & $\mathrm{N}^{\mathrm{c}}$ & $-_{-*}^{*}$ \\
\hline & & & & Not straight & $\mathrm{O}^{\mathrm{a}}$ & $\mathrm{N}^{\mathrm{c}}$ & $\left.-^{*}\right)$ \\
\hline & Black & 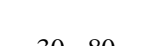 & $1.50-2.00$ & Not straight & $\mathrm{O}^{\mathrm{a}}$ & $\mathrm{nN}^{\mathrm{d}}$ & $\left.-^{*}\right)$ \\
\hline & & $30-80$ & & Not straight & $\mathrm{O}^{\mathrm{a}}$ & $\mathrm{nN}^{\mathrm{d}}$ & Puncture \\
\hline & & & & Not straight & $\mathrm{U}^{\mathrm{b}}$ & $\mathrm{nN}^{\mathrm{d}}$ & $\left.-^{*}\right)$ \\
\hline & & & $<1$ & Not straight & $\mathrm{O}^{\mathrm{a}}$ & $\mathrm{nN}^{\mathrm{d}}$ & $\left.-^{*}\right)$ \\
\hline & & & & Not straight & $\mathrm{O}^{\mathrm{a}}$ & $\mathrm{N}^{\mathrm{c}}$ & $\left.-^{*}\right)$ \\
\hline & & & & Not straight & $\mathrm{O}^{\mathrm{a}}$ & $\mathrm{nN}^{\mathrm{d}}$ & $\left.-^{*}\right)$ \\
\hline & & $15-20$ & $1.50-2.00$ & Not straight & $\mathrm{O}^{\mathrm{a}}$ & $\mathrm{nN}^{\mathrm{d}}$ & Puncture \\
\hline & & & & Not straight & $\mathrm{U}^{\mathrm{b}}$ & $\mathrm{nN}^{\mathrm{d}}$ & $\left.-^{*}\right)$ \\
\hline & & & & Straight & $\mathrm{O}^{\mathrm{a}}$ & $\mathrm{N}^{\mathrm{c}}$ & $\left.-^{*}\right)$ \\
\hline & & & & Not straight & $\mathrm{O}^{\mathrm{a}}$ & $\mathrm{N}^{\mathrm{c}}$ & $\left.-^{*}\right)$ \\
\hline & & & $1.50-2.00$ & Not straight & $\mathrm{O}^{\mathrm{a}}$ & $\mathrm{nN}^{\mathrm{d}}$ & $\left.-^{*}\right)$ \\
\hline \multirow[t]{17}{*}{ Bundle } & & & & Not straight & $\mathrm{O}^{\mathrm{a}}$ & $\mathrm{nN}^{\mathrm{d}}$ & Puncture \\
\hline & Brown & $30-80$ & & Straight & $\mathrm{U}^{\mathrm{b}}$ & $\mathrm{nN}^{\mathrm{d}}$ & $\left.-^{*}\right)$ \\
\hline & & & & Straight & $\mathrm{O}^{\mathrm{a}}$ & $\mathrm{N}^{\mathrm{c}}$ & $\left.-^{*}\right)$ \\
\hline & & & & Not straight & $\mathrm{O}^{\mathrm{a}}$ & $\mathrm{N}^{\mathrm{c}}$ & $\left.-^{*}\right)$ \\
\hline & & & & Not straight & $\mathrm{O}^{\mathrm{a}}$ & $\mathrm{nN}^{\mathrm{d}}$ & $\left.-_{-}^{*}\right)$ \\
\hline & & & & Not straight & $\mathrm{U}^{\mathrm{b}}$ & $\mathrm{nN}^{\mathrm{d}}$ & $\left.-^{*}\right)$ \\
\hline & & & & Straight & $\mathrm{O}^{\mathrm{a}}$ & $\mathrm{N}^{\mathrm{c}}$ & $\left.-^{*}\right)$ \\
\hline & & & & Not straight & $\mathrm{O}^{\mathrm{a}}$ & $\mathrm{N}^{\mathrm{c}}$ & $\left.-^{*}\right)$ \\
\hline & & & $1.50-2.00$ & Not straight & $\mathrm{O}^{\mathrm{a}}$ & $\mathrm{nN}^{\mathrm{d}}$ & $--^{*}$ \\
\hline & & & & Not straight & $\mathrm{O}^{\mathrm{a}}$ & $\mathrm{nN}^{\mathrm{d}}$ & Puncture \\
\hline & Dark brown & $30-80$ & & Not straight & $\mathrm{U}^{\mathrm{b}}$ & $\mathrm{nN}^{\mathrm{d}}$ & $-_{-*}^{*}$ \\
\hline & & & & Straight & $\mathrm{O}^{\mathrm{a}}$ & $\mathrm{N}^{\mathrm{c}}$ & $\left.-^{*}\right)$ \\
\hline & & & 1 & Not straight & $\mathrm{O}^{\mathrm{a}}$ & $\mathrm{N}^{\mathrm{c}}$ & $\left.-^{*}\right)$ \\
\hline & & & $<1$ & Not straight & $\mathrm{O}^{\mathrm{a}}$ & $\mathrm{nN}^{\mathrm{d}}$ & $\left.-^{*}\right)$ \\
\hline & & & & Not straight & $\mathrm{U}^{\mathrm{b}}$ & $\mathrm{nN}^{\mathrm{d}}$ & $-*)$ \\
\hline & Reddich brown & $30-80$ & 150 & Straight & $\mathrm{O}^{\mathrm{a}}$ & $\mathrm{N}^{\mathrm{c}}$ & $-*)$ \\
\hline & Kenuisil Diowil & $50-00$ & $1.50-2.00$ & Not straight & $\mathrm{O}^{\mathrm{a}}$ & $\mathrm{N}^{\mathrm{c}}$ & $-_{-*}^{*}$ \\
\hline \multirow{2}{*}{ Single } & & $130-260$ & $\pm 4-6$ & $\left.-^{*}\right)$ & $\mathrm{U}^{\mathrm{b}}$ & $\left.-^{*}\right)$ & $-_{-*}^{*}$ \\
\hline & iransparent & $30-80$ & $1.50-2.00$ & $\left.-^{*}\right)$ & $\mathrm{U}^{\mathrm{b}}$ & $\left.-^{*}\right)$ & $\left.-^{*}\right)$ \\
\hline
\end{tabular}

*it cannot be observed clearly; ${ }^{\text {a Organized; }}{ }^{\text {b Unorganized; }}{ }^{\mathrm{c}}$ Neat; ${ }^{\mathrm{d}}$ Not Neat. 
In this observation, there were also hair flakes raphide crystals (Figure 2(i)). It could be inferred bundle crystal consisting of single raphide crystals looked extremely thin. Therefore, these crystals looked like hair flakes when they were observed in weak magnification. These crystals generally had brown and black color. In general, long raphide crystal was \pm 4 - $6 \mu \mathrm{m}$ thick while the short one was $\pm 1.50-2.00 \mu \mathrm{m}$. However, hair flakes raphide crystal had $<1 \mu \mathrm{m}$ of thickness.

In terms of length, there were also small raphide crystals that were only \pm 15 - $20 \mu \mathrm{m}$ long (Figure 2(d)). These crystals generally had black color. It was often found in the form of crystal bundle that was not straight edge, not neat organized, unorganized and punctured. They were more likely to be found in idioblast cells. These crystals looked like styloid when they were observed in weak magnification.

In this research, color variation was less than it was in previous research. In the previous research, Chairiyah et al. [23] found crystal that had yellow and greenish yellow color in porang. Although raphide crystals relatively had few color variations, small raphide crystals that were smaller in size compare to the other types were found. On the other hand, it was known that there was a thickness variation of raphide crystals in this observation, i.e. Long raphide crystal generally was $\pm 4-6 \mu \mathrm{m}$ thick, and the short one was $\pm 1.50-2.00 \mu \mathrm{m}$ and hair flakes raphide crystal that had $<1 \mu \mathrm{m}$ of thickness. The difference of crystal variations size and shape might be triggered by genetics and environmental factors, e.g. planting media. The assumption was supported by Franceschi \& Nakata [3] stating that, crystal size variations in one species were influenced by intrinsic factors, e.g. cell function into crystal formation and environmental factors, e.g. calcium (Ca) content which was available during crystals formation.

\section{c. Prism Crystal}

Prism crystal found in porang corms had only two variations, i.e. square and hexagonal prism crystals (Figure 3). These crystals were generally found solitary and were $3-25 \mu \mathrm{m}$ long. Similar to this research, Amalia et al. [34] also explained that prism crystal could be found in porang corms. However, it only could be observed by using microscope at 1000 times magnification. These results were significantly different from Chairiyah et al. [23] that found eight prism crystal variations. On the contrary to this research, the research of Harijati et al. [33] showed that prism crystals were not found in porang. Novita and Indriyani [35] also clarified the similar result with Harijati's. They stated that $\mathrm{CaOx}$ crystals were found in porang, i.e. raphide, druse and X1 crystal. X1 crystal is a crystal that still cannot be observed clearly.

The difference of crystal variation size and shape might be influenced by genetics and environmental factors, e.g. planting media. The assumption was supported by Franceschi \& Nakata [3] who stated that, crystal size variations in one species were influenced by intrinsic factors. They are cell saving a function in forming crystal and environmental factors, e.g. calcium (Ca) content which was available during crystal formation.

\section{d. Styloid Crystal}

Styloid crystals found in porang corms had only one variation, i.e. group styloid crystal. These crystals had transparent color and were generally $3-20 \mu \mathrm{m}$ in length (Figure 4). They were generally found in group and

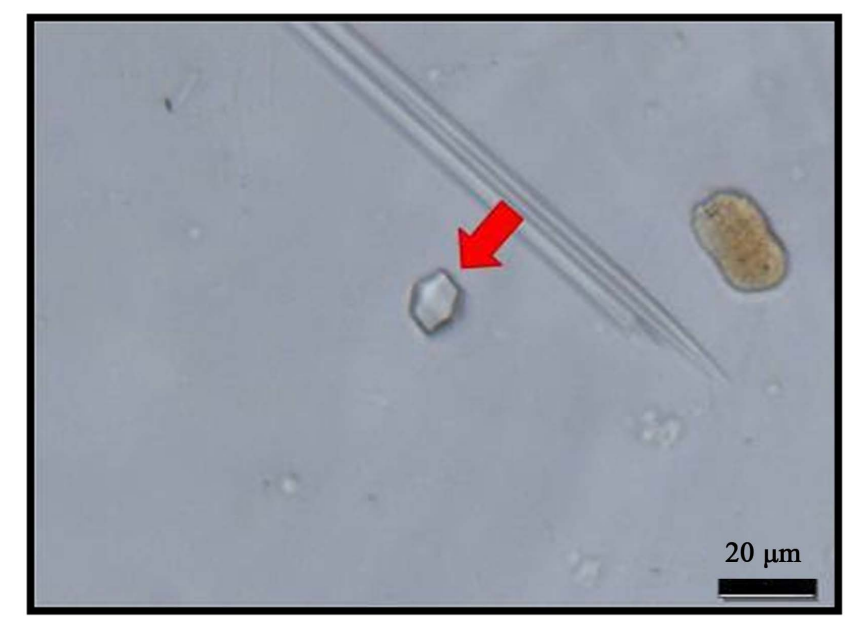

Figure 3. Hexagonal prism crystal that was found in porang corms (it is showed by red arrows). 


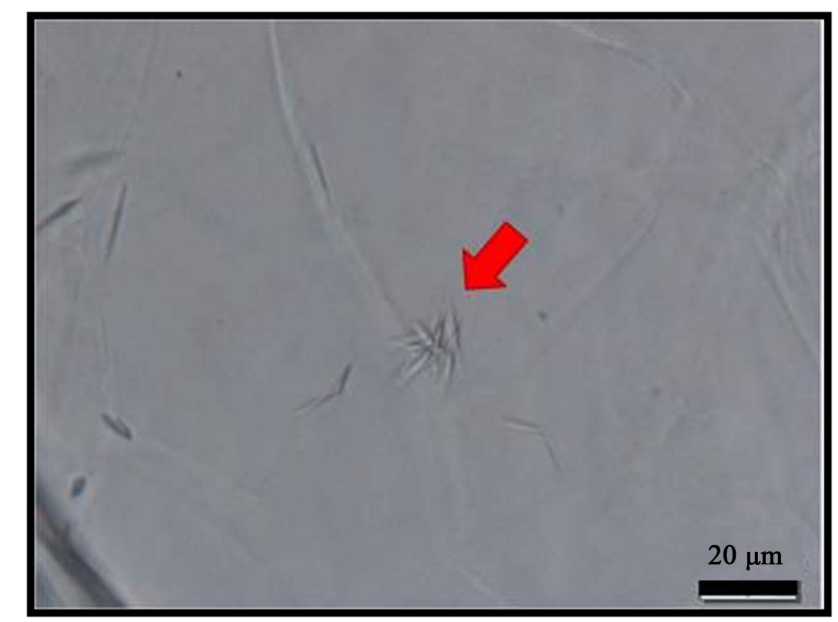

Figure 4. Styloid crystal that was found in porang corms (it is showed by red arrows).

were arranged irregularly. Based on the research of Amalia et al. [34], styloid crystals also were found in porang corms. These crystals only could be observed by using microscope at 1000 times magnification as well as prism crystals. This research showed significantly different finding from the previous. In the previous research, Chairiyah et al. [23] found eight prism crystal variations. Styloid crystals were found in genus Libertia (Iridaceae) were birefringent and were long and slender in shape with pointed ends. These crystals were approximately 60 $190 \mu \mathrm{m}$ in length [36]. The size of styloid crystal, based on Blanchon and Braggins [36], is extremely larger than it was found in this research. Harijati et al. [33] and Novita and Indriyani [35] dissimilarly explained that CaOx crystals were widely found in porang, i.e. raphide and druse crystal. The difference of crystal variations size and shape might be due to genetics and environmental factors, e.g. planting media. The assumption was supported by Franceschi \& Nakata [3] who state that, crystal size variations in one species were influenced by intrinsic factors, e.g. cell saving a function in forming crystal and environmental factors, e.g. calcium (Ca) content which was available during crystals formation.

\section{Conclusion}

The variation of CaOx crystals tended to be same in porang corms at three harvest times. The variation of these crystals tended to be static. It can be said that $\mathrm{CaOx}$ crystal variations in porang corms were not affected by different harvest time in one period growth. Variation of styloid, prism, druse and raphide in porang corms at three different harvest times tended to be the same, in which each of them had 1, 2, 3 and 37 variations respectively. It is also known that raphide crystal has the greatest variation amount. On the contrary, styloid crystal has the fewest variation amounts. These abundance of a number of raphide crystal variations possibly due to its role as a defense mechanism in porang corms.

\section{References}

[1] Cao, H. (2003) The Distribution of Calcium Oxalate Crystals in Genus Dieffenbachia Schott. And The Relationship between Environmental Factors and Crystal Quantity and Quality. Thesis, University of Florida, Florida.

[2] Cromack, K., Sollins, P., Graustein, W.C., Speidel, K., Todd, A.W., Spycher, G., Li, C.Y. and Todd, R.L. (1978) Calcium Oxalate Accumulation and Soil Weathering in Mats of The Hypogeous Fungus Hysterangium crassum. Soil Biology and Biochemistry, 11, 463-468. http://dx.doi.org/10.1016/0038-0717(79)90003-8

[3] Franceschi, V.R. and Nakata, P.A. (2005) Calcium Oxalate in Plant: Formation and Function. Annual Review of Plant Biology, 56, 41-71. http://dx.doi.org/10.1146/annurev.arplant.56.032604.144106

[4] Ilarslan, H.R., Palmer, G., Imsande, J. and Horner, H.T. (1997) Quantitative Determination of Calcium Oxalate and Oxalate in Developing Seeds of Soybean (Leguminosae). American Journal of Botany, 84, 1042-1046. http://dx.doi.org/10.2307/2446147

[5] Libert, B. and Franceschi, V.R. (1987) Oxalate in Crop Plants. Journal of Agricultural and Food Chemistry, 35, 
926-938. http://dx.doi.org/10.1021/jf00078a019

[6] Mazen, A.M.A., Zhang, D. and Franceschi, V.R. (2003) Calcium Oxalate Formation in Lemna Minor: Physiological and Ultrastructural Aspects of High Capacity Calcium Sequestration. New Phytologist, 161, 435-448. http://dx.doi.org/10.1111/j.1469-8137.2004.00923.x

[7] Prychid, C.J. and Rudall, P.J. (1999) Calcium Oxalate Crystals in Monocotyledons: A Review of Their Structure and Systematics. Annals of Botany, 84, 725-739. http://dx.doi.org/10.1006/anbo.1999.0975

[8] Volk, G.M., Goss, L.J. and Franceschi, V.R. (2004) Calcium Channels Are Involved in Calcium Oxalate Crystals Formation in Specialized Cells of Pistia stratiotes L. Annals of Botany, 93, 741-753. http://dx.doi.org/10.1093/aob/mch092

[9] Webb, M.C. (1999) Cell-Mediated Crystallization of Calcium Oxalate in Plants. The Plant Cell, 11, 751-761. http://dx.doi.org/10.1105/tpc.11.4.751

[10] White, P.J. and Broadley, M.R. (2009) Biofortification of Crops with Seven Mineral Elements Often Lacking in Human Diets-Iron, Zinc, Copper, Calcium, Magnesium, Selenium and Iodine (Research Review). New Phytologist, 182, 49-84. http://dx.doi.org/10.1111/j.1469-8137.2008.02738.x

[11] Kuo-Huang, L.-L., Ku, M.S.B. and Franceschi, V.R. (2007) Correlations between Calcium Oxalate Crystals and Photosynthetic Activities in Palisade Cells of Shade Adapted Peperomia glabella. Botanical Studies, 48, 155-164.

[12] Korth, K.L., Doege, S.J., Park, S.H., Goggin, F.L., Qin Wang, Gomez, S.K., Liu, G., Jia, L. and Nakata, P.A. (2006) Medicago truncatula Mutants Demonstrate The Role of Plant Calcium Oxalate Crystals as An Effective Defense Against Chewing Insects. Plant Physiology, 141, 188-195. http://dx.doi.org/10.1104/pp.106.076737

[13] Barabe, D., Lacroix, C., Chouteau, M. and Gibernau, M. (2004) On the Presence of Extracellular Calcium Oxalate Crystals on the Inflorescences of Araceae. Botanical Journal of the Linnean Society, 146, 181-190. http://dx.doi.org/10.1111/j.1095-8339.2004.00318.x

[14] Kartasapoetra, A.G. (1991) Pengantar Anatomi Tumbuh-Tumbuhan (Tentang Sel dan Jaringan). PT Rineka Cipta, Jakarta.

[15] Pitojo, S. (2007) Suweg. Kanisius, Yogyakarta, 37-44.

[16] Prychid, C.J., Jabaily, R.S. and Rudall, P.J. (2008) Cellular Ultrastructure and Crystal Development in Amorphophallus (Araceae). Annals of Botany, 101, 983-995. http://dx.doi.org/10.1093/aob/mcn022

[17] Genua, J.M. and Hillson, C.J. (1985) The Occurrence, Type and Location of Calcium Oxalate Crystals in the Leaves of Fourteen Species of Araceae. Annals of Botany, 56, 351-361.

[18] Grayum, M.H. (1990) Evolution and Phylogeny of the Araceae. Annals of the Missouri Botanical Garden, 77, 628-697. http://dx.doi.org/10.2307/2399668

[19] Mayo, S.J., Bogner, J. and Boyce, P.C. (1997) The Genera of Araceae. The Trustees, Kew.

[20] Keating, R.C. (2003) Leaf Anatomical Characters and Their Value in Understanding Morphoclines in the Araceae. The Botanical Review, 68, 510-523. http://dx.doi.org/10.1663/0006-8101(2002)068[0510:LACATV]2.0.CO;2

[21] Cote, G.G. (2009) Diversity and Distribution of Idioblasts Producing Calcium Oxalate Crystals in Dieffenbachia seguine (Araceae). American Journal of Botany, 96, 1245-1254. http://dx.doi.org/10.3732/ajb.0800276

[22] Cote, G.G. (2012) Distribution of Calcium Oxalate Crystals in Floral Organs of Araceae in Relation to Pollination Strategy. American Journal of Botany, 99, 1-12. http://dx.doi.org/10.3732/ajb.1100499

[23] Chairiyah, N., Harijati, N. and Mastuti, R. (2013) Variation of Calcium Oxalate (CaOx) Crystals in Porang (Amorphophallus muelleri Blume). American Journal of Plant Sciences, 4, 1765-1773. http://dx.doi.org/10.4236/ajps.2013.49217

[24] Liu, P., Zhang, S. and Zhang, X. (1998) Research and Utilization of Amorphophallus in China. Acta Botanica Yunnanica, 10, 48-61.

[25] Chua, M.F.Y. (2011) An Investigation of The Biology and Chemistry of The Chinese Medicinal Plant, Amorphophallus konjac. Disertasi, University of Wolverhampton, Wolverhampton.

[26] Hamadina, E.I. (2012) Origin of Vines, Feeder Roots and Tubers in Yam (Dioscorea Spp.): The Tuber Head or The Primary Nodal Complex? Nigerian Journal of Agriculture, Food and Environment, 8, 67-72.

[27] Çaliskan, M. (2000) the Metabolism of Oxalic Acid. Turkish Journal of Zoology, 24,103-106.

[28] Moore, G., Sanford, P. and Wiley, T. (2006) Perennial pastures for Western Australia. Department of Agriculture and Food Western Australia, Bulletin 4690, Perth.

[29] Middleton, C.H. and Barry, G.A. (1978) A Study of Oxalate Concentration in Five Grasses in the Wet Tropics of Queensland. Tropical Grasslands, 12, 28-35.

[30] Ilarslan, H., Palmer, R.G. and Horner, H.T. (2001) Calcium Oxalate Crystals in Developing Seeds of Soybean. Annals 
of Botany, 88, 243-257. http://dx.doi.org/10.1006/anbo.2001.1453

[31] Harijati, N., Chairiyah, N., Kartika, S.D. and Handayani, R. (2009) Morfologi kristal kalsium oksalat pada Amorphophallus campanulatus. Prosiding Keanekaragaman Hayati, Seminar Nasional Biologi XX dan Kongres PBI XIV UIN Maliki, Malang, 517-523.

[32] Sakai, W.S., Hanson, M. and Jones, R.C. (1972) Raphides with Barbs and Grooves in Xanthosoma sagittifolium (Araeae). Science, 178, 314-315. http://dx.doi.org/10.1126/science.178.4058.314

[33] Harijati, N., Arumingtyas, E.L. and Handayani, R. (2011) Pengaruh Pemberian Kalsium Terhadap Ukuran dan Kerapatan Kristal Kalsium Oksalat pada Porang (Amorphophallus muelleri blume). Jurnal Pembangunan dan Alam Lestari, 1, 72-139.

[34] Amalia, B.R., Harijati, N. and Mastuti, R. (2014) Pengaruh Pupuk Nitrogen Terhadap Kerapatan Kristal Kalsium Oksalat pada Umbi Porang (Amorphophallus muelleri Blume). Natural B, 2, 271-276.

[35] Novita, M.D.A. and Indriyani, S. (2013) Kerapatan dan Bentuk Kristal Kalsium Oksalat Umbi Porang (Amorphophallus muelleri Blume) pada Fase Pertengahan Pertumbuhan Hasil Penanaman dengan Perlakuan Pupuk P dan K. Jurnal Biotropika, 1, 66-70.

[36] Blanchon, D.J. and Braggins, J.E. (2009) Styloid Crystals in the Genus Libertia (Iridaceae). New Zealand Journal of Botany, 47, 39-42. http://dx.doi.org/10.1080/00288250909509791 